\title{
The Corona Case and the Increasing Cases of Racism and Xenophobia against Chinese Ethnic Groups in the World
}

\author{
Zunsyika Zahra Zatira \\ Universitas Diponegoro \\ Email: zunsyikazahrazatira@gmail.com \\ Muhammad Pambudi Prakoso \\ Universitas Muhammadiyah Yogyakarta \\ Email:pambuddi123@gmail.com
}

\begin{abstract}
The development of international relations studies is marked by the increasingly complex global issues that occur in the life of the world community. At present, the research of international relations does not focus on the subject of war and peace. Still, it is developing on more substantial issues about human rights being manifested in daily life. The world community is confronted with the problem of racism related to the realization of human rights. A global phenomenon that has powerful historical roots and occurs in various fields of human life, starting from politics, economics, socioculture, to sports. Unfortunately, acts of racial discrimination (racism) are increasingly developed by the existence of extremist groups who like violent behavior, physical and non-physical. The coronavirus that spreads in almost all countries in the world makes the number of racism and expressions of hatred towards Chinese people also jumps sharply. It is because the first case of the coronavirus occurred in Wuhan City, the capital of Hubei Province, China. The disease from this virus is then transmitted to people and spread almost everywhere in the world. As a result of the outbreak of this disease, the level of racism and expressions of hatred towards the Chinese people has increased dramatically, primarily through social media. The research method used was a qualitative method with a literature study used secondary data. The results of this study indicate significant increases in racism and xenophobic cases around the world during the Corona Virus.
\end{abstract}


Understanding of this research may contribute to the awareness of people around the world about racism and xenophobia.

Keywords: Racism, Xenophobia, Ethnic, Chinese, Coronavirus

\begin{abstract}
Abstrak
Perkembangan studi hubungan internasional ditandai dengan semakin kompleksnya isu global yang terjadi dalam kehidupan masyarakat dunia. Saat ini, penelitian hubungan internasional tidak berfokus pada masalah perang dan perdamaian. Namun, hal itu berkembang pada isu-isu yang lebih substansial tentang hak asasi manusia yang dimanifestasikan dalam kehidupan sehari-hari. Masyarakat dunia dihadapkan pada masalah rasisme terkait dengan realisasi hak asasi manusia. Fenomena global yang memiliki akar sejarah yang kuat dan terjadi di berbagai bidang kehidupan manusia, mulai dari politik, ekonomi, sosial budaya, hingga olahraga. Sayangnya, tindakan diskriminasi rasial (rasisme) semakin berkembang dengan adanya kelompok ekstrimis yang menyukai perilaku kekerasan, fisik maupun non fisik. Virus corona yang menyebar hampir di seluruh negara di dunia membuat jumlah rasisme dan ungkapan kebencian terhadap masyarakat Tiongkok juga melonjak tajam. Pasalnya, kasus pertama virus corona terjadi di Kota Wuhan, ibu kota Provinsi Hubei, China. Penyakit dari virus ini kemudian ditularkan ke manusia dan menyebar hampir ke mana-mana di dunia. Akibat merebaknya penyakit ini, tingkat rasisme dan ekspresi kebencian terhadap masyarakat China meningkat drastis, terutama melalui media sosial. Metode penelitian yang digunakan adalah metode kualitatif dengan studi pustaka menggunakan data sekunder. Hasil penelitian ini menunjukkan peningkatan signifikan kasus rasisme dan xenofobia di seluruh dunia selama virus Corona. Pemahaman penelitian ini dapat berkontribusi pada kesadaran orang-orang di seluruh dunia tentang rasisme dan xenofobia.
\end{abstract}

Kata Kunci: Rasisme, Xenophobia, Etnis, Tionghoa, Coronavirus

INTRODUCTION

Coronavirus or 2019-nCoV has claimed hundreds of lives and tens of thousands infected. This virus is straightforward to spread and first appeared in Wuhan, one of the cities 
in China. Rumors about the source of the emergence of this virus range from food to poultry animals. It is because there is no clear information about the origin of the development of the virus (merdeka.com, 2020).

Wuhan is one of the largest cities in China and is a vital transportation area in central China, which is located about 700 miles $(1100 \mathrm{~km})$ south of Beijing ((HAN), 2020), about 500 miles west of Shanghai, and 600 miles north of Hong Kong. Wuhan airport has direct flights to major cities in Europe, six weekly flights to Paris, three times to London, and five times to Rome.

In December 2019, a group of cases of "pneumonia with no known cause" was associated with the Huanan seafood wholesale market. This market has thousands of stalls selling various animals, such as bats, fish, birds, chickens, guinea pigs, snakes, deer spots, and other wild animals. After the coronavirus causes the disease, suspicion also arises that it is sourced from animals.

Most coronaviruses circulate among animals. However, six species have evolved and are capable of infecting humans. They are, such as in Middle Eastern Respiratory Syndrome (MERS), Severe Acute Respiratory Syndrome (SARS), and four other coronaviruses causing mild respiratory symptoms like a cold, from human to human (CDC, 2020). According to DR. Peter Daszak, the president of the EcoHealth Alliance, non-profit environmental health said that the coronavirus has similar genetic sequences to bat animals. According to the world health organization (WHO), the Covid-19 outbreak is a global pandemic. The WHO's Director-General Tedros Adhanom Ghebreyesus predicts that cases of exposure to the coronavirus will still increase. "In the past few weeks, the number of cases outside China and other countries have tripled (Arnani, 2020).

Reporting from Worldometers, here are some of the countries and regions that have confirmed the Covid-19 case until Thursday $(03 / 12 / 2020)$.

\begin{tabular}{|c|l|c|}
\hline No. & \multicolumn{1}{|c|}{ State Name } & Cases \\
\hline 1 & China & 80,790 \\
\hline 2 & Italy & 12,462 \\
\hline 3 & Iran & 9,000 \\
\hline 4 & South Korea & 7,755 \\
\hline 5 & France & 2,281 \\
\hline 6 & Spain & 2,277 \\
\hline 7 & Germany & 1,908 \\
\hline 8 & United State & 1,289 \\
\hline
\end{tabular}




\begin{tabular}{|c|l|c|}
\hline No. & \multicolumn{1}{|c|}{ State Name } & Cases \\
\hline 9 & $\begin{array}{l}\text { Diamond Princess } \\
\text { Cruises }\end{array}$ & 696 \\
\hline 10 & Switzerland & 652 \\
\hline 11 & Japan & 639 \\
\hline 12 & Norway & 629 \\
\hline 13 & Denmark & 514 \\
\hline 14 & Netherlands & 503 \\
\hline 15 & Sweden & 500 \\
\hline 16 & United Kingdom & 456 \\
\hline 17 & Belgium & 314 \\
\hline 18 & Qatar & 262 \\
\hline 19 & Australia & 246 \\
\hline 20 & Bahrain & 195 \\
\hline 21 & Singapore & 178 \\
\hline 22 & Malaysia & 149 \\
\hline
\end{tabular}

Generally, sentiment towards China, especially Wuhan people, are getting thicker as the development of such a hoax is intense. For example, religious sentiments call the Coronavirus outbreak deliberately spread by the Chinese regime to eradicate Muslims in Wuhan. Based on an explanation from the Ministry of Communication and Informatics who launched Wikipedia, the spread of Muslims in Wuhan is not too significant. The data describe that the majority of Wuhan citizens are Animism. Muslims in Wuhan is only $1.6 \%$ of the 11 million of total citizens (tirto.id, 2020).

The wave of racism towards ethnic Chinese also spread internationally. For Example, a Chinese citizen who uploaded a photo of his parents in front of a car got racist comments. "Stay in China until the flu leaves. Thank you," said a comment from one of the citizens. Meanwhile, several Vietnamese restaurants put "No Chinese" signs outside their restaurants (tirto.id, 2020).

Even in Japan, which is quite close to China, both geographically and racially, the hashtag \# ChineseDon't ComeToJapan became a trending topic on Twitter. In the southeastern district of Paris, known as a destination for those who enjoy Asian cuisine, the business declined in Pascal Collier's Vietnamese restaurant, a side effect of the Chinese corona fears that triggered panic. At the same time, it has created xenophobia (dislike or fear of people from other countries, or those considered foreign).

Some customers started asking staff on duty if they were Chinese, based on Collier's story, whose father-in-law is Vietnamese and works by managing the kitchen and serving traditional dishes. "There is a barrier to psychosis that 
is unfounded and unconsciously inherent among people around the Asian and Asian communities," said the restaurant owner, and experienced a decrease in income of around $40 \%$ for the first few weeks of 2020 compared to the same period last year. Similar to the case of Chinese citizens, other Asian communities are the largest community in France. They consist of Cambodians and Laotians, and there exists one of the largest Vietnamese communities abroad a relic of the former French citizens of Southeast Asia. Asians in France this week made the Twitter hashtag \#Jenesuispasunvirus ("I'm not a virus") to fight racial attitudes. Racist incidents, insults, and insults received support from school playgrounds to supermarkets. Based on the confession of Laetitia Chhiv, who is a member of the association for young people of Chinese descent." We have a student from China in Strasbourg who was yelled at by a woman who told him not to touch the avocado he wanted to buy," Chhiv was quoted as saying by Antara. "Racism against Asians spreads faster than the virus (tirto. id, 2020).

Therefore, it is fascinating to understand Racism and Xenophobia of the Chinese ethnic groups that are overgrowing throughout the world during the Coronavirus outbreak.

\section{RESEARCH METHOD}

The method used in this research was library research. The data obtained were written data from online and print media. All data collected were intended to get a picture of the community groups associated with racialism cases throughout the world. The researchers chose the case of countries that represent several continents because racism against Chinese is not only happening in Europe or America but also Asia.

\section{THEORETICAL FRAMEWORK}

\section{Racism}

Racism is often used loosely and without much consideration to describe the hatred and negative feelings of an ethnic group or "community" towards other groups, as well as the various actions that result from these attitudes. However, the anticipation of one group against another group is expressed with seriousness and brutality that goes far beyond group-centered prejudice and arrogance (Fredrickson, 2003).

Whereas racism, according to Kwame Anthony Appiah, is understood as the belief with inheritable characteristics possessed 
by members of the human species, which enable people to distinguish them into a smaller racial group, such that all members of this race have specific characteristics. Traits and tendencies are similar, so they do not have it together with other members of the race.

Racism is an ideology that justifies the dominance of certain racial groups against other groups. Included in this sense is a feeling of excessive superiority towards certain social groups. Racial discrimination has three levels, such as individual, organizational, and structural. On the individual level, racial discrimination is in the form of racist attitudes and behavior. On the organizational level, racial discrimination is seen when policies, rules, and legislation only benefit certain groups. Structurally, racial discrimination can be traced when one social institution imposes restrictions and restrictions on other institutions (Suharto, 2001).

Racism is closely related to the dominance and subordination of one social group over another. The object of racism is also vulnerable to stereotypes, hatred, and violence (both physical and non-physical), which occur repeatedly. Even if negotiations emerge, minorities are still defeated.
Based on the above definitions, the researchers assume that the behavior of the differentiation of one group, leading to acts of violence can occur anywhere, including during coronavirus outbreak in the world. The presence of immigrant communities from China who are a minority is the object of strong racism targets.

\section{Human Security}

Conceptually, there is some debate when discussing the concept of Human Security. However, in this paper, the researchers will present various conceptual views about human security, especially those that apply to European countries.

In Europe, human security is seen as based on human security itself in individuals and society, deciding as "freedom from belief" and "freedom from desire." Human security threats are related to protection from genocide and slavery and natural disasters, storms or floods, to the most basic rights such as food, health, and housing. The application of the concept of human security was first proposed by the European Security Capability Study Group report in Barcelona. In human security, the welfare of citizens is essential. They can avoid various threats 
and also multiple sources, even oppression from the representative state apparatus, disease epidemics, widespread crime, natural disasters, or accidents. (Anggoro, 2011).

In 1994, the UNDP (UN Development Program) declared the concept of Human Security, which included economic security, food security, health security, environmental security, personal security, community security, and political security. In short, UNDP states, "first, safety from such chronic threats such as hunger, disease, and repression. And, second, protection from the sudden and hurtful disruption in the patterns of daily life, whether in homes, in jobs or communities." In general, the definition of Human Security, according to UNDP, includes "freedom from fear and freedom from want." The UNDP idea thus directly links Human Security with Human Rights and humanitarian law.

Structurally, the UNDP views represent the European countries' view because most of the influential countries in the region are members of UNDP with donor status, such as the United Kingdom, which contributed $\$ 233$ million, the Netherlands, Norway, and Sweden contributed more than $\$ 100$ million.
Likewise, with the European Union itself, which provided more than \$921 million (\$226 million came from the European Commission and the rest came from European Union member countries) (Paul Sciarone, 2011).

In a broader context, Europe also has a human rights protection process through a mechanism under the umbrella of the Organization of Security and Cooperation in Europe (OSCE) whose membership includes the US and countries in Eastern Europe. In Latin America and Africa, more or less, the same agreements and mechanisms exist, but their effectiveness is still far below the performance and regional mechanisms found in Europe. According to David Beetham, what has been practiced in Europe is an example of the manifestation of cosmopolitan democracy that should be extended to other parts of the world (Beetham, 2007).

Some types of discrimination experienced by people of Chinese descent that we will bring to this journal include:

1. Economics such as the decline in income of Chinese restaurants due to excessive fear of the Coronavirus

2. Socio-culture such as harassment is targeted at bloody 
Chinese communities due to extreme fear of the Coronavirus such as bullying in schools and isolation of people of Chinese descent

3. Bullying on Social Media as reported by the Daily Mail, a report from L1ght, an organization that used to measure the level of toxicity in cyberspace, shows that the expressions of hatred for Chinese people on Twitter have increased, This hate speech is included in the hashtags circulating like \#Kungflu, \#Chinesevirus, and \#communistvirus.

Based on the above perspective, the researchers consider that racial discrimination in the world is part of violations of the international campaign on the protection of humanity, especially related to personal security and community security. In other words, the concept of human security is relevant to the needs of research on the spread of racism cases against ethnic Chinese due to the Coronavirus, mainly when human security is associated with human rights issues. In this case, the researchers want to build a framework for thinking that in the social world, everyone has the opportunity or ability and freedom to live anywhere. Freedom here is in the sense of being free from fear, threats, and hatred.

\section{RESULT AND DISCUSSION}

The pandemic of coronavirus 2019-20 has succeeded in increasing prejudice, xenophobia, conversion, resistance, and racism towards Chinese people and people in East Asia and Southeast Asia, and appearances throughout the world.

Here are some cases of racism and xenophobia against ethnic Chinese races throughout the world.

\section{Australia}

In Australia, quoted from the January 31, 2020 edition of SBSNews, there were reports about members of the Chinese-Australian and Asian-Australian community. They were targets of humiliation and racism, with many physical attacks and bullying on social media.

At a Woolworths supermarket in Port Hedland, Western Australia, a person reported an incident whereby a staff member removed and refused entry to customers who appeared to be of Asian descent, claiming it was to prevent the spread of the novel coronavirus. A witness to the incident made a complaint upheld by Woolworths. He confirmed that the staff member 
had been wrong, apologized for the incident, and said the authorities were conducting a full investigation into the incident (News Y., 2020).

Besides suggestions on social media to cull the Chinese race and "burn down" China to stop the epidemic, there was another persecution on March 20, 2020. A student wearing a mask in Hobart, Tasmania, was told, "You've got the virus" and "go back to your country" before being punched, leaving him with a bruised eye and broken glasses. The reason for the attack was partly attributed to the cultural differences in wearing masks in Eastern and Western cultures. Chinese restaurants and establishments in Sydney and Melbourne have seen a dramatic drop in business, with trade declining by over $70 \%$.

According to an online Ipsos MORI poll, 23\% of Australian respondents would consider in the future, avoiding people of Chinese origin to protect themselves from coronavirus.

\section{South Korea}

South Korean websites have been flooded with comments calling on the government to block or expel Chinese and racist remarks about Chinese eating habits and hygiene.
A popular Seoul seafood restaurant frequented by Chinese tourists posted a sign saying "No entry for Chinese" before taking it down Wednesday after an online backlash (NEWS, 2020).

More than 650,000 South Koreans have signed an online petition filed with the presidential Blue House, calling for a temporary ban on Chinese visitors. Some conservative opposition lawmakers publicly back these steps, and about 30 people rallied near the Blue House on Wednesday, demanding the government ban Chinese tourists immediately.

"Unconditional xenophobia against the Chinese is intensifying" in South Korea, the mass-circulation JoongAng Ilbo newspaper said in an editorial Thursday. "Infectious diseases are a matter of science, not an issue that can be resolved through an emotional outpouring."

\section{The United States}

After news broke that someone attending Arizona State University had the virus, Ari Deng, a Chinese American, said she sat down at a study table on the Tempe, Arizona, campus near five other students (NEWS, 2020).

Deng, who was the only Asian, said the other students began 
whispering. "They got tense, and they quickly gathered their stuff and just left at the same time."

In a new business class, a nonAsian student "said 'Not to be racist, but there's a lot of international students that live in my apartment complex. I try my best to keep my distance, but I think it's a good precaution for all of us to wash our hands," Deng said.

"It stings, but I don't let it take up room in my mind or weigh on my conscience," she said.

Meanwhile, the University of California, Berkeley's health services center, removed an Instagram post-Thursday that said, "fears about interacting with those who might be from Asia and guilt about these feelings" were a normal reaction to the coronavirus outbreak.

"No matter how much time we spend in this country, at times we are almost immediately viewed as a foreigner," Gregg Orton, the national director of the National Council of Asian Pacific Americans, said. "It's a pretty frustrating reality for many of us."

\section{Hong Kong}

The virus has deepened antiChinese sentiment in Hong Kong, where months of street protests against Beijing's influence have roiled the semi-autonomous Chinese city (NEWS, 2020).

Last week, Hong Kong Chief Executive Carrie Lam suspended ferry and high-speed train services to the mainland and reduced flights between Hong Kong and Chinese cities.

Tenno Ramen, a Japanese noodle restaurant in Hong Kong, was refusing to serve mainland customers.

"We want to live longer. We want to safeguard local customers. Please excuse us," the restaurant said on Facebook.

\section{Europe}

In France, they use the hashtag JeNeSuisPasUnVirus (I am not a virus) on social media. Racist sentiments against citizens of Chinese descent have been reported in several countries, including France and Canada.

In France, residents of Chinese descent were angry when the local newspaper Le Courier Picard posted headlines "Alerte Jaune" (Yellow Alert) and "Le péril Jaune?" (Yellow Danger?) with photos of Chinese women wearing protective masks. The newspaper hurriedly apologized, stating they did not intend to use "Asia's bad stereotypes." 
Meanwhile, in Canada, some media reported racial sentiments towards the Chinese people there, especially in the city of Toronto. Twitter users from Toronto, Terry $\mathrm{Chu}$, and several other mothers worried about the "inevitable wave of racism" as the coronavirus spreads. In York, a suburb of Toronto, several students' parents circulated and signed an online petition asking students who had just returned from China in the last 17 days to be prohibited from going to school.

Racist sentiments against the Chinese also happened in Canada following the SARS outbreak in 2003. When panic broke out due to the plague, many Chinese businesses in Canada experienced a slump in income (Indonesia B. N., 2020).

\section{Japan}

Many of the Japanese people who have popularized anti-Chinese hashtags on social media to call for a travel ban for Chinese visitors in the midst of them coming to Japan for virus-related treatments. One tweet said, "Please stop Chinese tourists immediately," while speaking, "I am anxious that my child might catch the virus (NEWS, 2020)."

One candy shop in Hakone, a city which is also a hot spring in western Tokyo, recently made headlines after posting a note saying, "The Chinese who entered the shop were requested." On Wednesday, Menya Hareruya, a popular ramen chain in Sapporo on the island of Hokkaido, northern Japan, posted a sign that said: "There is no entry for Chinese tourists."

\section{Southeast Asia}

Last weekend, several hundred residents in the Indonesian tourist city of Bukittinggi marched to the Novotel Hotel, where some 170 Chinese tourists were staying, protesting their entrance into Indonesia (NEWS, 2020).

They blocked roads near the hotel to prevent the Chinese, who had arrived a day earlier, from getting out of the hotel. Local authorities decided to send the visitors back to China later in the day.

More than 400,000 Malaysians have signed an online petition calling for a ban on Chinese travelers and urging the government to "save our family and our children.”

A former police officer and town mayor said that he burned a Chinese flag on Friday in front of the National Press Club in Manila to protest the problems China has brought to the Philippines and other Southeast Asian countries. 
It includes the virus and Beijing's claim to disputed islands in the South China Sea.

The Philippine president's office stated, "Let us not engage in discriminatory behavior, nor act with any bias towards our fellowmen. The reality is everyone is susceptible to the virus."

\section{CONCLUSION}

Covid-19 is a new virus becoming a pandemic today and comes from Wuhan, China. Some studies reveal that winged mammals, bats, are the cause of the origin of this virus. Until now, this virus has penetrated 200 countries, with 529,614 total cases. The existence of this virus invites the world to become sentimental towards the people of Asia, especially China. Chinese citizens experience various kinds of discrimination from multiple groups, as some examples presented above. Some countries do openly blacklist Chinese citizens not to visit their countries. It is a form of state responsibility to the community to avoid the spread of the Covid-19 virus, which is increasingly widespread. However, the researchers feel that this method is considered too excessive if they have to discriminate against one party.
The Chinese government's policy to lock all access out of this country is the right action. In addition to avoiding the spread of the virus that is increasingly widespread, the Chinese government also applies 14-day isolation for Chinese citizens and non-citizens who want to enter Chinese territory. Discrimination is not an appropriate action, but the Chinese government's policy can also be considered and applied globally to other countries.

\section{BIBLIOGRAPHY}

(HAN), H. A.-0. (2020, January 8). Outbreak of Pneumonia of Unknown Etiology (PUE) in Wuhan. Retrieved from HAN Archive - 00424 | Health Alert Network (HAN): https://web.archive.org/ web/20200109112902/https:// emergency.cdc.gov/han/ han00424.asp

Anggoro, K. (2011). Keamanan Nasional, Pertahanan Negara dan Ketertiban Umum. http:// ditpolkom.bappenas.go.id/ basedir/,pdf, 4-5.

Arnani, M. (2020, March 12). Kompas.com. Retrieved from adi Pandemi Global, Ini Daftar 121 Negara dan Wilayah yang Konfirmasi Kasus Virus Corona: https://www.kompas.com/tren/ 
$\mathrm{read} / 2020 / 03 / 12 / 074100165 /$ jadi-pandemi-global-inidaftar-121-negara-danwilayah-yang-konfirmasi-kasus

Beetham, D. (2007). Democracy and Human Rights. Ibid, 17.

CDC, N. C. (2020, January 13). Novel Coronavirus 2019 ( $n$ CoV2019), Wuhan, China. Retrieved from Novel Coronavirus 2019| CDC: https://web.archive.org/ web/20200114084712/https:// www.cdc.gov/coronavirus/ novel-coronavirus-2019.html

Fredrickson, G. M. (2003). Racism: A Short History. New Jersey: Princeton University Press.

Indonesia, B. N. (2020, March 5). 'Saya tidak ingin virus coronamu di negaraku': Kisah mahasiswa Singapura alami serangan rasisme di London. Retrieved from BBC News Indonesia: https: / / www.bbc.com/ indonesia/dunia-51749212

merdeka.com. (2020, February 6). Cerita Lengkap Asal Mula Munculnya Virus Corona di Wuhan. Retrieved from merdeka.com: https://www. merdeka.com/dunia/ceritalengkap-asal-mula-munculnyavirus-corona-di-wuhan.html

NEWS, A. (2020, February 2). Fears of new virus trigger anti-China sentiment worldwide. Retrieved from AP NEWS: https:// apnews.com/04f18aafe1074a1c 06b4203edcbdc661

News, A. (2020, February 13). Student evicted from Perth house due to landlord's fears of coronavirus outbreak. Retrieved from ABC News: https://www. abc.net.au/news/2020-02-12/ foreign-student-evicted-fromperth-house-over-coronavirusfears/11959530

News, Y. (2020, February 1). Woolworths employee 'kicks out Asian customer' over coronavirus fears. Retrieved from Yahoo! News: https://au.news.yahoo. com/woolworths-employeekicked-asian-customer-out-ofsupermarket-over-coronavirusfears-020043272.html

Paul Sciarone, S. V. (2011). The Protection of Human Rights in Europe. Pemajuan dan Perlindungan Hak Asasi Manusia, 16.

Suharto. (2001).Modal kedamaian sosial. Retrieved from www. policy.hu: http://www. policy.hu/suharto/modul_a/ makindo_20.htm

tirto.id. (2020, February 4). Gelombang Diskriminasi dan Rasisme yang Muncul Akibat 
Hoaks Corona. Retrieved from tirto.id: https://tirto.id/ gelombang-diskriminasi-danrasisme-yang-muncul-akibathoaks-corona-ewFs 